\title{
Cost and Benefit Analysis of Tax Incentives in Ethiopia
}

\author{
Mekonen Kassahun(PhD) \\ Ethiopian Civil Service University \\ Public Sector Reform Research Center
}

\begin{abstract}
Ethiopia introduced various Economic Reform Programs including tax reforms since 1992 with the aim of encouraging trade, investment and hence development. Those reforms are geared towards promoting investment, supporting industrial development and broadening the tax base in the view of financing the need of government expenditure. However whether those government assumption and stated objectives were achieved is debatable and questionable. Therefore, one ways to address those issues is to analyze the cost and benefit analysis of tax incentives which is the objective of this article. To address those issues, this article employs both primary and secondary data. The primary data was collected through questionnaire from 800 respondents, and interview, and focus group discussion of officials and investors. Secondary data is gathered from different publication, documents, financial and non financial reports; and Ethiopian Investment Agency(EIA) \& Ethiopian Revenue and Tax Authority (ERCA) rules, regulations and proclamations. Since measurement of the cost and benefit of tax incentives is hard, to arrive at the measurable definition of cost and benefit this article adopted the World Bank cost and benefit analysis framework of tax incentives. And the result revealed that, the objective of tax incentives is failed to meet its intended objectives. This is because, the amount of employment created is not much with what is planned, and from investors who take tax incentives only $20 \%$ in number and $15 \%$ in the amount of capital they registered are operational. Furthermore, most of the investments are in areas where they can be commenced without any tax incentive and the amount of revenue forgone for one birr additional investment is about 7 birr on average. And we can conclude that; there is large revenue forgone with low; realized investment, output growth, created employment opportunities, and export growth. Thus, this reduces the countries opportunities to invest in public infrastructure, public services, social support and poverty reduction programs.
\end{abstract}

Keywords: cost and benefit, tax incentives

DOI: $10.7176 / \mathrm{RJFA} / 12-7-03$

Publication date: April $30^{\text {th }} 2021$

\section{INTRODUCTION}

UNCTAD defines tax incentives as reduction in the tax burden of investors aimed to encourage private investment in selected sectors and areas of a country. Those incentives may include reduction in profit tax rates, tax holidays, accelerated depreciation, loss carry forwards and reduction or free from tariffs on imported equipment, components, and raw materials, or increased tariffs to protect the domestic market.

Many countries allow tax incentives by expecting economic benefits from investments in the form of, jobs creation, transfer of technology and technical skill development and an increase in tax revenues (Gray, 1987). Other researchers such as Gruber ( 2005) also concluded that investment decisions are relatively sensitive to tax incentives and it is a powerful tool in determining investments flow. On the other hand, other researchers such us Bolink (2004) are against tax incentives because he believe that tax incentives can create: inequalities, revenue loss, and can erode the revenue base.

To evaluate whether tax incentives are beneficial or not, it is important to analyze based on the fundamental principles of taxation, Efficiency, Equity and Economy. With this regard tax incentives may be against efficiency because; investors may try to invest in areas where they are eligible for tax incentives rather than decide to invest based on the forces of demand and supply. Tax incentives may also violate horizontal and vertical equity principle of taxation by imposing the tax burden on investors not based on their ability to pay but by the relative importance of their investment. The importance of the investment which is eligible for tax incentive may also be determined without doing any cost benefit analysis of the incentives rather it is determined by policy makers or politicians intention. Tax incentives may also violate the economic principle of taxation by increasing the administrative and compliance cost of taxation and may increasing discretionary power of tax officials and create loopholes in the tax system that may cultivate corruption.

If this so, why tax incentives exist and why countries including Ethiopia try attract private investment by offering different tax incentives. The reason is, if properly design and administer, tax incentives can create positive externalities which benefit the country in general and the society in particular.

However different studies show that tax incentive cannot bring the intended result if a country did not support the tax incentive scheme with other measures. For example Mauritius, Costa Rica, Ireland and Malaysia are good examples in attracting investment by only improving; economic and political conditions, skilled labor 
force, good infrastructure, open trade for exporters, good rule of law, and effective investment promotion systems (Steven et.al. 2007). Similar study in Uganda and Indonesia also show that, by terminating their former tax incentives they attract more investments.

Other study by Steven et.al (2007) compare the Tax Incentives Reforms and FDI Performance Index in four MENA countries (Egypt, Jordan, Morocco and Tunisia) and find that after they introduce tax incentive reforms from 1994 to 1997, except in Tunisia, the FDI Performance Index is showing rapidly increasing after the reform the FDI, performance index in the other countries is not changed and even decrease in the case of Jordan. On the other hand they found a stable or increasing trend is observed in Uganda when tax incentives are eliminated.

Another study by Bird (2008), indicate that tax incentives are popular both in developing and developed countries but their outcome most of the time are redundant and ineffective and they reduce revenue and complicate the tax system without achieving their intended objectives. Further, Bird based on his analysis suggested that it is not important to eliminate tax incentives rather they should be simple, keep records, and evaluate the result. Another study by Khan (2006) also supported the above argument where any incentive policy requires constant monitoring to prevent leakage, imposing an additional burden on tax authorities because excessive use of tax incentives complicates administration, facilitates evasion, and encourages corruption.

Other empirical results on the effect of tax incentive on attracting private investment and achieving the expected shows mixed result. For example in Mauritius, Costa Rica, Ireland and Malaysia there is success stories in attracting investment by offering tax incentives but in other countries such as the transitional economies(South East Europe countries, OECD) tax incentives is not effective in attracting investments (Narine,2013). On the other hand Uganda in 1997 Eliminated tax holidays and introduced uniform tax rate and as result investment to GDP ratio; Tax revenue to GDP ratio and FDI increases substantially. Similarly Indonesia totally eliminated selective incentives, and lowered corporate tax rate from $45 \%$ to $35 \%$ in 1984 , as a result FDI increases. Egypt in 2005 also eliminated all income tax exemptions and lowered the business income tax rate from $40 \%$ to $20 \%$ and owing to this as compared to $2004 / 2005$ it was double the flow of FDI in $2005 / 6$ tripled in 2006/7and quadrupled in 2007/8 (Narine,2013). Therefore, due to this mixed result, it requires empirical investigation through cost and benefit analysis framework which is also the focus of this article.

Although, the benefit of tax incentives are controversial, most African countries, though they are poor and are unable to raise adequate tax revenues to meet their increasing expenditure requirements, so far they still give a wide range of tax incentives,. However the expected result is not achieved, as the percentage of foreign investment flows to Africa is the lowest as compared to the other regions of the world.

The same is also true in Ethiopian, where the government introduces various tax incentives reforms regardless of increasing criticism by different scholars in the country for the reason tax incentives are economically inefficient and lead to misallocations of public funds. Ethiopia has introduced a tax reform program, since 1992 and amended several times during the last thirty years including in; 1996, 2002, 2012 and 2014. The country offers different tax incentives by expecting; to encourage and expand investment; to increase the inflow of capital and speed up the transfer of technology into the country; to enhance and promote equitable distribution of investments among regions. Those incentive packages include; customs duty exemption, and tax holidays for selected sectors like manufacturing, agro-processing, agricultural development, and information communication.

Despite Ethiopia has continued giving tax incentives to private investors, the incentive did not meet its intended objectives. This may be because investors abuse the incentives either by diverting the incentives from the eligible areas for investment incentives to other areas or by using the incentives for their own benefit. Due to these and others, FDI inflows to the country increased in absolute term but it is very low in relative term ( NBE, 2017/18). As the intended objective of the incentive reforms is to boost the manufacturing sector, but still the manufacturing sector accounts for only $26 \%$ of GDP and even the targeted manufacturing sector contribution to GDP if far behind small and medium enterprise. On the other hand, when we see the trend in revenue forgone due to tax incentives in Ethiopia, it shows us that an increase from 3.73 Billion Birr in 2005/06 to more than 52 Billion Birr in 2017/18 in absolute amount and increased from $2.99 \%$ in $2005 / 06$ to $7.52 \%$ of GDP in $2017 / 18$ (ERCA, 2018). At the same time the budget deficit of the country reaches more than 2.429 Billion USD in 2018 which is $3.03 \%$ of GDP (MoFED, 2017/ 18).

Therefore, tax incentives can be justified only if they bring net benefit to society as a whole or anticipated losses in revenue and economic efficiency and increased cost in administration have to be outweighed by the intended and achievable long-term economic and revenue growth. This requires, appraisal before its introduction and evaluation on an on-going basis. To estimate this net benefit, we need to conduct cost-benefit analysis starting from concrete specification of costs and benefits. Therefore based upon the cost and benefits of tax incentives framework it is important to analyze whether those benefits outweighs costs. With this regard, the key questions which is addressed in this article are what are the actual benefit and costs of tax incentives in Ethiopia. To do so, this article try to analyze the cost and benefit of tax incentives based on different theoretical assumption \& principles of tax incentives. 


\section{Materials and Methods}

This article employs both primary and secondary data. The primary data was collected through questionnaire from 800 respondents, and interview, and focus group discussion of officials and investors . Secondary data is gathered from different publication, documents, financial and non financial reports; and Ethiopian Investment Agency(EIA) \& Ethiopian Revenue and Tax Authority (ERCA) data base, rules, regulations and proclamations.

Since the definitions of the cost and benefit of tax incentives are controversial, to arrive at the measurable definition of cost and benefit associated with any given tax incentive make it hard. Therefore to address this issue the article employs World Bank cost and benefit analysis framework of tax incentives. Those are:

\section{Tax incentive costs}

Tax incentives have both direct and indirect costs.

$>$ The direct costs of a fiscal incentive are the revenue forgone as a result of giving the tax incentives to an investor that would have invested without incentives.

$>$ The indirect costs, which are relatively difficult to measure, include:

* Distortions created by tax incentives in the form of encouraging new investments that that can discourage the existing ones.

* Time and money spent by investors in lobbying the government officials for tax incentives.

* Time and money spent by investors for qualifying and obtaining tax incentives.

* Revenue lost due to illegal tax incentives, for example when the investment is not qualifying of tax incentive but due to different reasons get tax incentive

Tax incentive Benefits

* Additional costs for administering tax incentives.

They also categorized direct and indirect benefits.

$>$ One benefit which is to easy to measure is job created due to tax incentives

$>$ Other benefit is spillover benefits such as:

$\checkmark$ Investments in technology or technology transfer - for example research and development or high-tech industries - that improve worker skills and productivity.

$\checkmark \quad$ Infrastructure projects that enhance investment.

$\checkmark \quad$ Investments that create jobs in areas with high unemployment for example unskilled labor.

$\checkmark$ Anchor investments - that can give multiplier effects through signaling and by creating backward linkages in the country

\section{RESUILT AND DISCUSSION}

Even though, in Ethiopian it is difficult to quantify benefits and costs, however, there are some data's relating to forgone revenue estimated by Ethiopian Customs and Revenues Authority. The Ethiopian Revenue and Custom Authority statistical report indicate that, there is increasing trend in revenue forgone from 3.73 Billion Birr in $2005 / 06$ to 52 Billion Birr on 2017/18. As a share of GDP, the amount of revenue forgone increased from $2.99 \%$ in $2005 / 06$ to $7.52 \%$ in $2017 / 18$ (ERCA, 2018). According to the statistical report revenue forgone from import duties and tax exemptions are on average $51 \%$ of total revenue and $7.52 \%$ of GDP per year and had shown average growth rate of $49.22 \%$ per year.

The Ethiopian government plans to enhance the Tax to GDP to $20 \%$, in $2017 / 18$ but it remains $14.6 \%$ as of 2012/13 (MoFED, 2012/13) and even falls to $12.9 \%$ in $2013 / 14$ and further reduced to $11 \%$ in $2017 / 18$. In order to divert the fall in revenue to GDP ratio ERCA and IMF recommended two conflicting measures. On the one hand ERCA authorities try to rely on tax administrative reforms; on the other hand IMF Staff recommended the authorities to reduce tax expenditure and tax incentives and improve tax collection, (IMF, 2014).

Similarly, tax incentive requires resources to manage and administer it, and may also discourage investment by creating distortion between sectors and can create fertile ground for corruption and rent seeking activities but still they are not quantified. Therefore in order to achieve the government's objective to reach a middle-income country by 2025 (IMF, 2014) it is important to minimize the large revenue lost from tax incentives and other because the loss in revenue makes it impossible to finance Public services and Infrastructure which are the key factor for economic development and growth. For those reasons assessing the cost and benefit of tax incentives which is the focus area of this article is important for understanding whether tax incentives bring the intended result or not.

\subsection{Trends in Tax Revenue in Ethiopia}

Tax revenue in Ethiopia in the past decade has shown a strong growth. As it has shown in table below total tax revenue has grown highly, reaching more than 157 billion birr in 2016/17 from 14 billion birr in 2005/6 which shows a total growth of $1121 \%$ or almost $101 \%$ yearly bases. However, even the total tax revenue is increasing through time, still the ratio of tax revenue to GDP remains very low even by the Sub-Saharan Africa standard, which is only $11 \%$ in $2017 / 18$ increases from $8.22 \%$ in $2005 / 6$. Tax revenue in Ethiopia has not been 
characterized with similar distribution between direct taxes and indirect taxes. As we have seen in table below contribution of indirect taxes is significant with $95.58 \%$ in $2007 / 8$ and decline to 52.03 in 2016/17.

\subsubsection{Direct Taxes}

The total direct taxes collected in Ethiopia was 3,783,610, 000 birr or $27.04 \%$ of the overall tax revenue collected in $2007 / 8$ and increased to $44,105,470,000$ birr in $2016 / 17$ or $28.05 \%$ contributes to the overall tax revenue. From direct taxes in Ethiopia, business profit taxes score the highest with $66.4 \%$ contribution to the total direct tax in 2007/8 and 71.75 in 2016/17 and followed by tax on employment with $20.93 \%$ in $2007 / 8$ and $14.7 \%$ in 2016/17, and withholding tax with 9.1\% contribution in 2007/8 6.99\% in 2016/17. From the direct taxes the least performance was observed in royalty tax followed by capital gain tax in 20016/17. Even though, the performance of royalty and capital gain tax increases from $2007 / 8$ to $2016 / 17$ but its contribution is still insignificant.

Table 1: Direct Tax in Ethiopia in million birr

\begin{tabular}{|c|c|c|c|c|c|c|c|c|c|c|c|}
\hline no & Type of tax & $2007 / 8$ & $2008 / 9$ & $2009 / 10$ & $2010 / 11$ & $2001 / 12$ & $2012 / 13$ & $2013 / 14$ & $2014 / 15$ & $2015^{\prime} 16$ & $2016 / 17$ \\
\hline 1 & $\begin{array}{l}\text { direct tax } \\
\text { total }\end{array}$ & 3,783.61 & $5,396.26$ & $8,693.44$ & $13,149.87$ & $17,076.23$ & $20,211.71$ & 27,711.02 & $32,596.41$ & $38,597.73$ & $44,105.47$ \\
\hline 2.1 & $\begin{array}{l}\text { Employme } \\
\text { nt tax }\end{array}$ & 795.25 & $1,017.37$ & $1,219.90$ & $1,611.45$ & $2,220.47$ & $2,658.21$ & $3,777.16$ & 4,916.69 & $6,003.10$ & $6,486.96$ \\
\hline 3.2 & Rental tax & 0.00 & 0.00 & 0.00 & 0.00 & 0.00 & 0.00 & 0.00 & & 0.96 & 0.00 \\
\hline 4 & Profit tax & $2,512.21$ & $3,661.76$ & $6,388.21$ & $8,474.15$ & $12,770.47$ & $14,709.65$ & $20,410.67$ & $23,449.03$ & $27,793.69$ & $31,646.65$ \\
\hline 5 & $\begin{array}{l}\text { Dividend \& } \\
\text { lottery tax }\end{array}$ & 79.33 & 118.86 & 200.75 & 192.91 & 436.55 & 872.24 & 946.04 & $1,125.10$ & $1,341.10$ & $1,993.32$ \\
\hline 6 & $\begin{array}{l}\text { Capital } \\
\text { gain tax }\end{array}$ & 0.00 & 0.00 & 0.00 & 0.00 & 0.00 & 72.19 & 76.03 & 215.42 & 123.63 & 156.20 \\
\hline 7 & Royalty tax & 0.00 & 0.00 & 0.00 & 3.28 & 9.67 & 6.87 & 6.17 & 13.28 & 13.80 & 16.54 \\
\hline 8 & $\begin{array}{l}\text { Withholdin } \\
\mathrm{g} \operatorname{tax}\end{array}$ & 344.83 & 530.14 & 801.77 & $1,105.67$ & $1,444.67$ & $1,665.26$ & $2,136.04$ & $2,425.81$ & $2,747.46$ & $3,081.55$ \\
\hline 9 & Interest tax & 51.99 & 68.13 & 82.81 & 152.12 & 194.40 & 227.29 & 358.91 & 451.07 & 573.99 & 724.25 \\
\hline
\end{tabular}

\section{Source ERCA}

\section{1.2. Indirect Taxes}

Indirect tax revenues, which account for about $95.5 \%$ in 2007/8 of total tax revenues in Ethiopia but declined its contribution to $52.03 \%$ in $2016 / 17$. Indirect taxes are heavily dependent on taxes related to international trade, excise duties and VAT on imports and on domestic goods and services. From the indirect taxes in 2007/8 VAT on imports (with 26.47\%), custom duty (with 24.68\%) and VAT on domestic goods and services (with 17.86\%) contributes to the overall indirect tax. On the other hand in 2016/17 VAT on imports outstrip custom duty with $28.23 \%$ contribution to the overall indirect tax followed by domestic goods and services VAT with $28.22 \%$ and custom duty with $27.70 \%$ contribution to the indirect tax. The least contributor is surtax in both $2007 / 8$ and 2016/17.

Table 2: Indirect Tax in Ethiopia

\begin{tabular}{|c|c|c|c|c|c|c|c|c|c|c|c|}
\hline no & Type of tax & $2007 / 8$ & $2008 / 9$ & $2009 / 10$ & $2010 / 11$ & $2001 / 12$ & $2012 / 13$ & $2013 / 14$ & $2014 / 15$ & $2015^{\prime} 16$ & $2016 / 17$ \\
\hline 1 & $\begin{array}{l}\text { Indirect tax } \\
\text { total }\end{array}$ & $13,376.49$ & 15005.7 & 21676.17 & 29800.84 & 40804.15 & 46518.4 & 54862.81 & 63396.77 & 65025.58 & 81763.45 \\
\hline 1.1 & Goods VAT & $1,109.09$ & $1,950.74$ & $2,902.63$ & $2,350.51$ & $4,823.92$ & $5,063.47$ & $7,803.15$ & $10,673.00$ & $8,344.33$ & $9,755.03$ \\
\hline 1.2 & Service VAT & 0.00 & 0.00 & 896.24 & $3,155.00$ & $5,006.96$ & $9,203.66$ & $11,886.90$ & $16,322.49$ & $16,640.67$ & $16,832.51$ \\
\hline 1.3 & $\begin{array}{l}\text { VAT } \\
\text { withholding }\end{array}$ & 832.14 & $1,053.60$ & $1,288.41$ & $1,996.94$ & $2,499.07$ & $2,778.52$ & $3,673.56$ & $4,343.75$ & $4,715.05$ & $6,377.38$ \\
\hline 1.4 & Excise tax & 36.88 & 19.99 & 22.25 & 25.93 & 31.21 & 38.85 & 38.81 & 24.79 & 24.78 & 27.87 \\
\hline 1.5 & T0T & 109.90 & 121.62 & 155.56 & 221.14 & 314.07 & 310.21 & 378.71 & 394.40 & 462.88 & 521.95 \\
\hline 1.6 & Stump duty & $2,134.09$ & $2,833.30$ & $3,583.29$ & $5,219.51$ & $6,316.50$ & $7,126.77$ & $7,784.00$ & $8,897.77$ & $10,878.43$ & $13,321.54$ \\
\hline 1.7 & Custom duty & $3,891.82$ & $3,944.09$ & $5,853.74$ & $7,719.98$ & $11,090.97$ & $12,761.12$ & $15,371.44$ & $17,571.84$ & $21,632.71$ & $22,652.92$ \\
\hline 1.8 & Import excise & 857.97 & $1,028.39$ & $1,417.64$ & $2,043.83$ & $2,758.95$ & $3,764.91$ & $4,197.01$ & $4,582.34$ & $5,659.68$ & $6,954.60$ \\
\hline 1.9 & Import VAT & $3,541.17$ & $4,069.52$ & $4,204.14$ & $6,309.69$ & $8,585.93$ & $12,172.83$ & $13,775.97$ & $16,744.51$ & $19,572.36$ & $22,268.63$ \\
\hline 1.10 & Import surtax & 492.65 & $2,210.20$ & $2,282.91$ & $3,480.61$ & $4,469.87$ & $6,522.38$ & $7,443.31$ & $8,899.72$ & $9,986.07$ & $11,866.98$ \\
\hline 1.1 & Export tax & 0.00 & 0.00 & 0.00 & 0.00 & 0.00 & 0.00 & 0.11 & 0.06 & 0.24 & 0.01 \\
\hline
\end{tabular}

Source ERCA

\section{1.3. Potential Tax Revenue}

Many theoreticians believe better domestic revenues mobilization is vital to alleviate poverty and to improve infrastructure of a developing country (IMF, OECD, World Bank, UN). With this regard Ethiopia has shown a Substantial increase in domestic revenue mobilization but when we examine it in terms of the potential tax 
revenue, the country lags behind Sub Saharan African countries.

When we calculate the tax revenue to GDP ratio based on the developing countries threshold level $20 \%$, Ethiopia experiences a tax gap of 9\% of GDP which is equivalent to $163,195,123,764$ birr or 4,079,878,094.1 USD which is almost similar to the current total tax revenue collection in Ethiopia. When compare this tax gap with other East African countries which is only 5\% for Tanzania 2\% in Kenya, $7.8 \%$ in Uganda, and $8.5 \%$ in Rwanda where the Ethiopian tax Gap is very high. The gap in Ethiopia is nearly equal to the current tax revenue and tax exemptions contributed significantly for this gap therefore, the country requires to address to issue in order to bridge the gap and enhance revenue mobilization potential.

\subsection{Cost of Tax Incentives in Ethiopia}

The costs of tax incentives are not only revenue loss to the government; rather they are multi- dimensional. Those multidimensional costs of tax investment can be categorized as direct and direct costs. The direct cost of tax incentives are related with the revenue forgone by the government. On the other hand its indirect costs are related with; distortions created by the tax incentive because there is difference in treatment between those investments which are qualified for incentive and those who are not, costs related to the administrative of incentives and social costs because incentives can create and develop rent-seeking behavior in the society and further they can lead to corruption. Base up on direct and indirect costs the next sections of this research evaluate the Ethiopian tax incentive as follows:

\subsubsection{The direct Cost of Tax Incentives in Ethiopia}

\subsubsection{Tax Exemptions as Revenue Foregone}

The direct costs of tax incentive are the revenue forgone by the government due to tax incentives. And one of way of measuring direct costs of tax incentives is "tax expenditure" and can be defined as "government revenues foregone as a result of differential or preferential treatment of specific sectors, activities, regions, or agents" (Tyson, 2014). With this definition, the scope of tax expenditure is not only limited to only tax incentives, but also to deductions.

Based up on the above indicators this article try to compare the cost of tax expenditure with selected east African countries. However, the problem to make comparison is that tax expenditure report is not clearly stated in Ethiopia.. Therefore, to tackle the problem this article employs data from different sources including; World Bank African development indicators, IMF data base and African Development Bank data base.

As the report of the ERCA and African development indicators of the world bank indicated in th table below, in Ethiopia revenue forgone from duties and tax exemptions is on average $51 \%$ of total revenue and $7.5 \%$ of GDP per annum and shows an annual average growth rate of $49.22 \%$ which indicates there is significant increase in tax incentives. This is also confirmed by Revenue Authority data base, where duties and tax exemptions (revenue forgone) shows a significant increase 3.958 billion in 2005/6 to 71.308 billion in 2016/17 or its total growth rate is about $1801.61 \%$. The highest growth rate was observed in $2007 / 8$ where tax exemption was increased by about $97.53 \%$. After that a steady growth rate near 20\% was observed till 2013. But in 2013/14 the rate of increase reaches to $61.65 \%$ which is almost three times from the rate of increase $2012 / 13$. After that tax exemption growth rate shown a sharp decline where it reaches 8.48\% in 2015/16 and 0.31 in 2017/18.

When we analyze year wise, the amount of tax exemption reaches its peak where tax incentives reaches 71 billion birr and more than $85 \%$ of total tax expenditure and $51 \%$ of total revenue. As interview result with officials indicate that, the problem with the tax administration is observed in considering and computing, tax incentives as part of government expenditures and also opportunity costs related to tax incentives is not determined. But based on the data obtained from other sources including World Bank data base, we can also observe similar trend when we compare the amount tax expenditures with percentage of Government expenditure. Tax expenditure were on average $23.41 \%$ of government expenditure in the given years and the highest was observed in 2014/15 with $33.28 \%$ of government expenditure.

The amount of government revenue loss due to tax incentives as we have seen in the above table indicate that on average it was estimated $7.52 \%$ of GDP and in absolute terms on average it is, about 71 billion birr which if by far higher to the annual average total health and education sector budget which is not more than 40 billion birr. This estimate shows that in the year 2017/18 alone.

From the type of taxes the highest exemption was seen in import VAT exemption where it contributes about $53.50 \%$ in $2005 / 6$ and 39.92 in $2016 / 17$, followed by custom duty with $30.88 \%$ in $2005 / 6$ and $20.78 \%$ in $2016 / 17$ and import surtax with $19.32 \%$ in $2016 / 17$ contribution to the overall tax exemption. The import VAT and custom duty exemption reaches $84.3 \%$ of all exemptions where the Ethiopian tax structure is heavily dependent up on custom duties and other incentive only $15.7 \%$ of the overall exemptions. Similarly trade related exemptions making up $85 \%$ of all tax exemptions. This shows that the Ethiopian tax incentive policy is much more skewed towards custom tax exemption followed by trade related taxes compared to the direct tax component. The reason behind this is as it is indicated in the interview result the administration of the tax exemption and the claiming process is easy and requires no more complex process. 
Table 3: Tax exemption in Million Birr

\begin{tabular}{|c|c|c|c|c|c|c|c|c|c|c|c|c|}
\hline Type of tax & $2005 / 6$ & 200617 & $2007 / 8$ & 200819 & $2009 / 10$ & 2010/11 & $2011 / 12$ & $2012 / 13$ & $2013 / 14$ & $2014 / 15$ & $2015 / 16$ & $2016 / 17$ \\
\hline Custom duty & $1,222.54$ & 1486.208 & 2556.09 & 3749.78 & $4,827.58$ & $4,778.00$ & $5,732.19$ & $6,638.10$ & $7,573.55$ & $13,045,05$ & $14,395.58$ & $14,819.82$ \\
\hline $\begin{array}{l}\text { Import excise } \\
\text { tax }\end{array}$ & 617.78 & 493.741 & 893.14 & 1160.47 & $1,955.28$ & $2,334.15$ & $3,149,67$ & $4,552.77$ & $6,149,18$ & $7,474,22$ & $7,860.91$ & $7,663.52$ \\
\hline Import VAT & $2,118.38$ & 2548.587 & 3592,38 & 5356.15 & $6,905.01$ & $8,943.21$ & $11,325.10$ & $12,626,10$ & $15,522.41$ & $26,157.72$ & $28,118.08$ & $28,471.12$ \\
\hline Import surtax & . & 390.267 & 2242.96 & 3251.41 & $4,392,36$ & $4,816.70$ & $5,260.46$ & $6,440.06$ & $7,562.42$ & $12,828.67$ & $13,936.20$ & $13,738.23$ \\
\hline $\begin{array}{l}\text { Import } \\
\text { withholding } \\
\text { tax }\end{array}$ & - & 0 & 431.57 & 1417.24 & $1,844.62$ & $2,108.20$ & 3,038.91 & $3,234.94$ & $3,734.73$ & $6,030.87$ & $6,780.56$ & $6,616.12$ \\
\hline Total & $3,958.70$ & $4,918,80$ & $9,716.14$ & $14,935.05$ & $19,924.85$ & $22,980.26$ & $28,506,33$ & $33,491.97$ & $40,542.29$ & $65,536.53$ & $71,091.33$ & $71,308.81$ \\
\hline Growth rate & & 24.25 & 97.53 & 53.71 & 33.41 & 15.33 & 24.05 & 17.49 & 21.05 & 61.65 & 8.48 & 0.31 \\
\hline $\begin{array}{l}\text { Ratio to tax } \\
\text { revenue } \\
\end{array}$ & & 35.15 & 50.59 & 64.31 & 56.55 & 46.28 & 40.94 & 40.39 & 38.65 & 51.99 & 49.92 & 45.37 \\
\hline $\begin{array}{l}\text { Ratio with } \\
\text { GDP }\end{array}$ & & 2.88 & 2.81 & 4.49 & 5.25 & 4.46 & 3.81 & 3.86 & 3.82 & 5.04 & 4.65 & \\
\hline $\begin{array}{l}\text { Ratio with } \\
\text { G.vbudg }\end{array}$ & & 14.25 & 21.76 & 23.4 & 38.96 & 27 & 23.26 & 23.48 & 24.8 & 33.81 & 28.21 & \\
\hline
\end{tabular}

Source ERCA, 2017 \& own calculation

When we compare the Ethiopian revenue forgone against some African countries, for example in Rwanda and Sierra Leone, more than one-third of tax revenues were given up as incentive, however the corresponding figure on Ethiopia is $51 \%$ percentage of tax revenue and $7.52 \%$ of GDP. If the Ethiopian government invests this amount of revenues to deliver basic public goods, such as health care and education, Ethiopian may relive from seeking foreign aid and credit to covers public expenditure for those services ( Tax Justice Network-Africa \& Action Aid International (2012:iv). When we analyze the tax incentives only, the result revealed that: Kenya, Uganda, Tanzania, and Rwanda are losing totally up to US\$2.8 billion a year from all tax incentives and exemptions and the corresponding figure for Ethiopia is USD 2.54 billion per year. But much of the revenue loss due to tax incentives is accepted when its objective is meet, however, this hardly true in almost all east African countries including Ethiopia (Tax Justice Network-Africa, 2012). This study also revealed that, this objective is not met as the first objective of tax incentives is creating employment opportunity, but to create one birr employment opportunity the country should give tax incentives more than 10 times which is not feasible.

\section{2.2. THE INDIRECT COSTS OF TAX INCENTIVES}

The indirect cost of tax incentives are relatively difficult to measure and may include:

\subsubsection{Distortions Created by Tax Incentives}

To justify tax incentive in Ethiopia, it should increase additional investment in sectors, and regions that should not be otherwise invested. When we evaluate the type of investments which are eligible for tax incentives in Ethiopia, most of the investments are invested either in areas that were relatively developed or in sectors that can be invested without incentives. For example, the total number of investments in Ethiopia in the last seven years is 10,750 investments in manufacturing, 7,166 in construction, 2,778 in hotel and restaurant, and 5,177 in agriculture. In terms of capital, manufacturing leads by above 1.3 trillion birr, followed by hotel and restaurant with above 106 billion investments, construction, above 100 billion birr and agriculture with only 65 billion birr. Regional wise Addis Ababa leads by 29,986 numbers of investments, followed by Amhara, with 7,832 and Oromia with 5,348 investments. The lower number of investment is observed in Gambella only 19 investments, SNNPR 914 investments and B. Gumez 945 investments.

Therefore, from the above data, we can conclude that, most of the investments are invested in sectors or areas where they could be invested without incentives except manufacturing and Agriculture. This is because when we see the star hotel and specialize restaurant investment which is the highest next to manufacturing with above 106 billion investment capital, but as the Ethiopian Tourism and culture minster report 2017, indicted there are below one hundred star hotels in the overall the country and this shows as that incentives was given for investments otherwise could be invested without tax incentives or there is high evasions of tax incentives. The same is true with construction sector investment where the total number of investment capital above 100 billion and significant part of custom duty exemption is given not to import machineries rather for dump trucks and vehicles which are not serving for their intended purpose. Region wise the number of investment is concentrated in areas where there is better investment climate and infrastructure such as Addis, Amhara, Oromia and Tigray where investment without incentives is possible.

The other important point to be raised with regard to tax incentives is the development forgone. Tax incentives waste government resources, which can be used alternatively for poverty reduction and to supply basic services. In this regard, the total amount of tax incentives from 2006- 2017 was above 384 billion and 
when we compare the amount which was expended for poverty reduction and supplying the basic service which is relatively similar and this shows us that if you invest this tax incentive amount on poverty reduction programs and supplying the basic service Ethiopia poverty level will decrease by substantial amount which can be similar with the past years poverty reduction performance. And the same is also true for the supplying the basic service.

Another important factor that tax incentives can create is redundancy of investments, which means the desire of investors to invest in specific area repeatedly because that area is eligible for investment incentives even though they did not have clear understanding on that specific investment. The basic example in Ethiopia are the Star hotel investment and construction machinery rent which are repeatedly investors prefer to invest without analyzing their benefit but for the sake of getting investment incentives. This result is also supported by the investor's perception survey and the result which is presented in the table below there is high redundancy ratio. When we compare this ratio with other east African countries it nearly similar, which indicates investment incentive create redundant investments.

Table: 4. Redundancy ratio Based on Investor Surveys

\begin{tabular}{|l|l|l|}
\hline Country & Year & Redundancy ratio \\
\hline Burundi & 2011 & 77 \\
\hline Rwanda & 2011 & 98 \\
\hline Kenya & 2012 & 61 \\
\hline Uganda & 2011 & 93 \\
\hline Ethiopia & 2018 & 90 \\
\hline
\end{tabular}

The other way tax incentive distorts the allocation of resources is because incentives violates the basic principles of taxation (neutrality and equity). With regard to this when both officials and experts and asked the current state of tax incentives violate the equity principal of taxation. As it is shown in the table below most of the respondents about $80.2 \%$ strongly agree and agree on the statement.

Table 5: tax incentive distortion on allocation of resource

\begin{tabular}{|l|l|l|l|l|l|l|l|l|l|l|}
\hline & \multicolumn{2}{l|}{$\begin{array}{l}\text { Strongly } \\
\text { Disagre }\end{array}$} & \multicolumn{2}{l|}{ Disagree } & \multicolumn{2}{l|}{$\begin{array}{l}\text { Somewhat } \\
\text { agree }\end{array}$} & \multicolumn{2}{l|}{ agree } & \multicolumn{2}{l|}{ Strongly agree } \\
\cline { 2 - 10 } & No & $\%$ & No & $\%$ & No & $\%$ & No & $\%$ & No & $\%$ \\
\hline $\begin{array}{l}\text { the current state of tax } \\
\begin{array}{l}\text { incentives violate the equity } \\
\text { principal taxation }\end{array}\end{array}$ & 319 & 41.16 & 302 & 38.96 & 55 & 7.09 & 51 & 6.58 & 47 & 6.06 \\
\hline
\end{tabular}

\subsubsection{Revenue Lost Due To Illegal Claiming and Approval of Tax Incentives In Ethiopia}

The first mechanism were revenue was lost due to illegal activities was, when the investment is not qualifying of tax incentive but, due to various reasons an investor can get tax incentives. But in this case as it was indicated by the respondents it is not common in Ethiopia tax incentive practice. But according to the focus group discussion respondents this was manifested in special operators( which is given by the tax authority as special operators) case were most of such operators was benefited from the tax incentive even though they are not eligible for the benefit.

The second mechanism where revenue lost occurs is due to illegal activities in the form of tax planning. In many developing countries including East African countries, tax planning can lead to a significant amount of revenue leakage, and even in some cases the leakage due to tax planning may exceed the revenue forgone from tax incentives. However, even though there is manifestation of such practice in Ethiopia its amount is not significant. And this implies that the tax avoidance strategy of investors through tax planning in case of tax holidays and exemptions is limited in Ethiopia.

\section{2.2.3. Common Forms Of Tax Incentive Abuses In Ethiopia \\ a. Over-valuation}

According to interview participants point view, when investors or importers import goods without tax incentives undervaluation is the main problem, on the other hand, when investors import goods with tax incentives overvaluation is a main problem. This is because tax incentives are conditional upon a certain minimum amount being invested; the value of assets can be manipulated to be eligible for incentive. Furthermore, overvaluation can be done in order to increase the value of deprecation when the firm starts paying income taxes. When the good is imported without incentives the investor may weigh the benefit he get from deprecation and the cost he pay in the form of custom duty, but this is not true for investor who is eligible for tax incentive because he did not pay custom duty and they did not have any cost rather they gain benefit from overvaluation in the form of deprecation.

\section{b. Abuse of Duty-Free Privileges}

A duty free privilege in Ethiopia is a type of investment incentive that includes exemption from customs duty on imported equipment, $15 \%$ of spare parts, and inputs which are used for the production of exportable goods. But the problem is that, once the machinery, vehicles, and inputs imported, there is no guarantee, and mechanism to 
ensure whether those items are served the intended purpose, rather except trucks the other items can be easily sold in the domestic market. If the exempted items are sold domestically, beyond the revenue forgone by the government they create market distortion in the form of decreasing price.

In order to avoid this many countries use different mechanisms such as restricting exemption to assets that are contributed to the fixed capital of the enterprise and verify continuously if the asset was used for the intended purpose and remain in the investment. Another method where countries applied was restricting exemption to machinery and exclude items such as vehicles, computers, refrigerators, and other home appliances for star hotel investment. But the experience in Ethiopia is different. As it was indicated by the respondents in table below majority of respondents $(74.43 \%)$ replied that, selling the equipment, is less likely but using the items for unintended purpose is common. This was also supported by the FGD and respondents response for the open ended questions. On the other hand, majority (71.48\%)of the respondent agree with the statement custom duty exempted goods such as construction materials, star hotels home appliances and imported inputs for the production of exportable goods are sold in the domestic market. Further, respondents was asked whether there is any mechanism the government uses to ensure the duty free items are not sold or serve for the intended purpose, majority of the respondents replied that the mechanism is very weak.

Table 6: Abuse of duty-free privileges

\begin{tabular}{|l|l|l|l|l|l|l|l|l|l|l|l|}
\hline & \multicolumn{2}{l|}{$\begin{array}{l}\text { Strongly } \\
\text { Disagr }\end{array}$} & \multicolumn{2}{l|}{ Disagree } & \multicolumn{2}{l|}{$\begin{array}{l}\text { Somewhat } \\
\text { agree }\end{array}$} & \multicolumn{2}{l|}{ agree } & \multicolumn{2}{l|}{ Strongly agree } \\
\cline { 2 - 11 } & No & $\%$ & No & $\%$ & No & $\%$ & No & $\%$ & No & $\%$ \\
\hline $\begin{array}{l}\text { duty free imported items are } \\
\text { served the intended purpose }\end{array}$ & 345 & 44.5 & 232 & 29.93 & 111 & 14.32 & 32 & 4.12 & 23 & 2.97 \\
\hline $\begin{array}{l}\text { duty free imported items are } \\
\text { sold in the domestic market }\end{array}$ & 431 & 55.61 & 123 & 15.87 & 143 & 18.45 & 43 & 5.55 & 35 & 4.52 \\
\hline $\begin{array}{l}\text { There is mechanism to ensure } \\
\text { whether duty free imported } \\
\text { items are served the intended } \\
\text { purpose rather they can be } \\
\text { sold in the domestic market }\end{array}$ & 333 & 42.96 & 234 & 30.19 & 102 & 13.16 & 52 & 6.71 & 54 & 6.97 \\
\hline
\end{tabular}

\subsubsection{Additional Costs for Administering Tax Incentives}

Administrating tax incentive, in addition to direct costs requires indirect costs and that is why ERCA and EIC have incentive departments with more than 50 employees. In most cases, tax incentives are difficult to administer because the tax and investment authorities required too many conditions and criteria's to check whether the investment is eligible for the tax incentive. On the other hand, giving incentives on ad hoc basis, may nurture corruption and rent seeking practice, therefore tax administration must ensure, first if the incentive rule and regulation is implemented correctly, second, if the specific investment qualify for tax incentive and third, the amount which is eligible for incentive is correctly reported by the respective investor.

With this regard when we evaluate the Ethiopian tax incentive administration, as it was raised in the official's interview and expert's focus group discussion, in case of applying the tax incentive rules and regulation there is no much problem observed. However, problems has been seen, once an investor qualify for tax incentive, midterm evaluation of tax holidays is not common, and this make it hard in ensuring whether the investor maintained or not the qualification criteria's which make him eligible for tax incentive. Consequently, respondents also mentioned that reporting the correct amount of tax incentive is not a common practice from investor's side, and officials try to investigate the correct amount and this makes the administration of tax incentive time consuming and costly.

\subsubsection{Opportunities for Corruption}

Many Scholars try to relate tax incentives with corruption and rent-seeking practice, but their relationship differs with the type of tax incentive granting mechanism. The choice is between granting tax incentive on automatic and objective approaches versus granting tax incentive on discretionary and subjective approaches. Corruption is assumed to be higher when tax incentives rules and regulations give higher discretionary power to officials and the rules and regulations are not clear.

With this regard to this, the Ethiopian tax rule is more biased to automatic or statutory base of granting tax incentive. However there are some cases where the rule gives discretionary power to officials which include, determining the time where the tax holiday starts, the number of years the tax holiday covers because it ranges from 2-15 years, and when deprecation of fixed assets starts(in the holiday period or after ). The other problem which is related in providing tax incentive is, if investor gets tax incentives which are not eligible for that incentive, the only measure taken by the tax authority is to with draw the privilege and repaid the amount of incentive without any legal sanction. And this may be one reason that can nurture corruption and rent-seeking practice. 


\subsection{Tax incentive Benefits in Ethiopia}

\section{3.1. Investment Created}

As the objective of providing tax incentives in Ethiopia is to boost the rate of private investment in areas and sectors where they are assumed undeveloped and can enhance the overall development of the country. With this regard, in the next part we try to evaluate the trend of gross domestic investment, private investment, operational investment in terms of sectoral and regional distribution after the major tax investment reform have been implemented in 2002.

As it is indicated in the figure below gross domestic investment rose from 1992 to in 1995. After that it slightly decrease in 1996, and did not show any significant change until the 2006 but start to decline in 2007. However, starting from 2008 domestic investment have increased and reaches 39\% of GDP in 2015 and starts to decline after that.

\section{Figure 1: Gross Domestic Investment as Percentage of GDP}

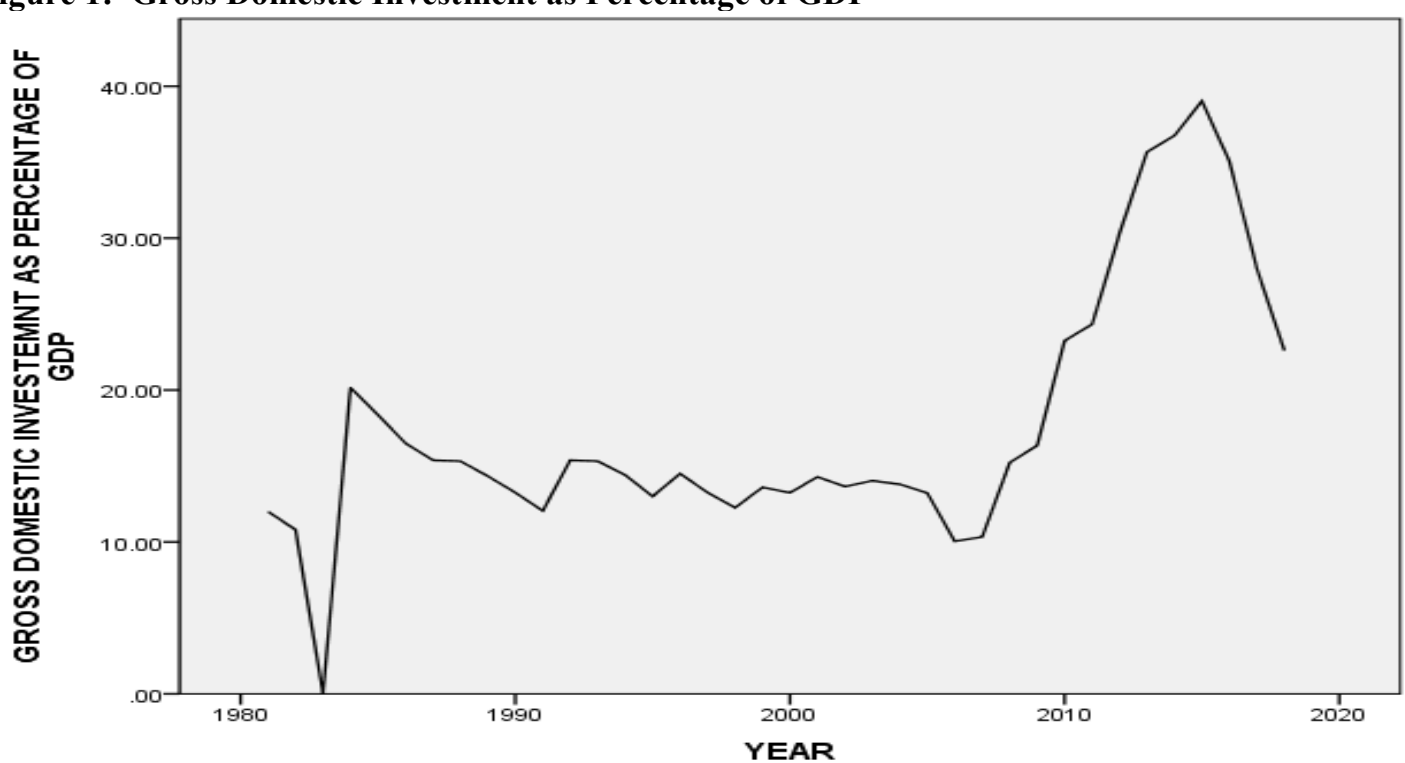

The contribution of private investment to gross domestic investment is very low as compared to. public investment. Thus, as we have seen in the figure below the share of domestic private investment to GDP shows greater increment in the given period of time. For example in 1991 it was below 5\%, but after 1992 up to 2012 it has shown slight improvement and reaches around 15\%. From 2013 onwards private investment to GDP ratio shows significant improvement and reaches around $21 \%$ which is nearly proportional to public investment and start to decline after that. The main reason for this improvement is due to a series of reforms and amendment of different polices, rules and regulations on investment and tax incentives were among others.

Figure 2: Trends of Domestic Private investment as share of GDP

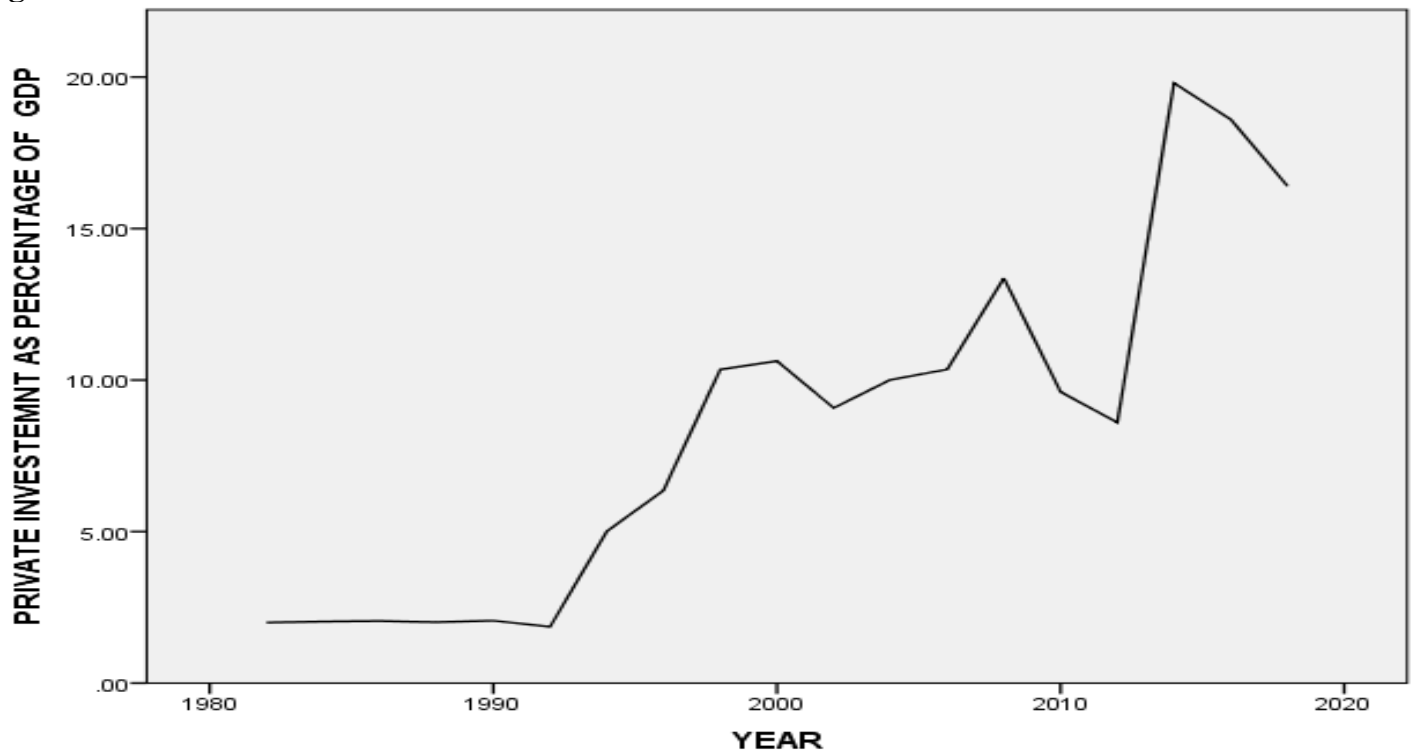


With regard to foreign direct investment, Ethiopia has shown strong performance especially after 2010. For instance in 2010 the country attracts FDI with investment capital 288m USD and further improved to 3.6bn USD in 2017 and this makes the country the second largest FDI recipient in Africa. This huge amount of investment was registered in manufacturing, due to the expansion of industrial parks in different parts of the country and the development of large infrastructural projects.

\subsubsection{Trends of Operational Investment}

Many studies such as Seruvatu and Jayaraman, (2001), indicate that, private investment is essential for economic growth, sustainable development and poverty reduction. However, what matters is; it is not the number of registered investment, but the number of operational investments. With this regard developing countries including Ethiopia performance is very poor. For example, in Ethiopia on average the number of operational investments is not more than $20 \%$ of number of registered investments and less than $15 \%$ of the registered capital( Mekonen 2015).

As it is indicated in Ethiopian investment proclamation, the main objective of rendering different investment incentive packages is to improve agricultural and manufacturing investment. When we analyze with this regard, Even though the rate of operational investment is very low compared to what is licensed, the percentage of investment who starts operation is highest in Agriculture( with 44\% in number and 36\% in capital), followed by construction( $34.33 \%$ and $36.72 \%)$ and manufacturing( $14.92 \%$ and $15.98 \%)$. From these percentages we can observe that, even though the government is targeted the manufacture sector, it was ranked third. Similarly, when we compare the amount of tax incentive received as we have seen above hotel sector with low rate of operation receives relatively the higher amount of tax incentive. This also shows us that the tax incentive is not meet its intended objectives.

Table 7. Operational Investment Projects by Sector ( 1992-2017)

\begin{tabular}{|c|c|c|c|c|c|c|}
\hline \multirow[b]{2}{*}{ Sectors } & \multicolumn{3}{|c|}{ Capital } & \multicolumn{3}{|c|}{ Number of Projects } \\
\hline & $\begin{array}{l}\text { Registered } \\
\text { capital in '000 } \\
\text { Birr }\end{array}$ & $\begin{array}{l}\text { Operational } \\
\text { capital in } \\
\text { '000 birr }\end{array}$ & $\begin{array}{l}\text { Percentage } \\
\text { of capital } \\
\text { operational } \\
\text { inv }\end{array}$ & $\begin{array}{l}\text { Registered } \\
\text { inv }\end{array}$ & $\begin{array}{l}\text { Operational } \\
\text { inv }\end{array}$ & $\begin{array}{l}\text { Percentage } \\
\text { of } \\
\text { operational } \\
\text { inv }\end{array}$ \\
\hline Agriculture, & $65,000,000$ & $20,622,278$ & $44 \%$ & 5,177 & 1,868 & $36.08 \%$ \\
\hline Manufacturing & $108,000,000$ & $15,899,256$ & $14.72 \%$ & 10,750 & 2,017 & $18.76 \%$ \\
\hline Hotels & $86,000,000$ & $2,885,820$ & $3.33 \%$ & 2,778 & 444 & $15.98 \%$ \\
\hline Construction & $42,500,000$ & $14,590,641$ & $34.33 \%$ & 7,166 & 2632 & $36 . .72 \%$ \\
\hline Other & $168,454,520$ & $16,495,183$ & $9.7 \%$ & 20,154 & 2,244 & $11.13 \%$ \\
\hline Grand & $469,954,520$ & $70,493,178$ & $15 \%$ & 46,025 & 9,205 & $20 \%$ \\
\hline
\end{tabular}

Source: EIC, 2019

\subsubsection{Employment created}

In many countries policymakers give tax incentives in areas where there is high unemployment, and relate tax incentive directly to a given number of new jobs creating and considered it as eligibility criteria to qualify for the tax holiday and other incentive. But the experience in Ethiopia is somewhat different, for example most criteria's for qualification of tax incentives are related with the amount of capital and the percentage of their exported than creating new jobs. Similarly in the investment rules and regulations of Ethiopia, contrary to other East African countries, there is no specific article which sets minimum domestic content requirement for investors. And this can help investors to hire foreign workers even unskilled labour as we observe in most Chinese and Indian companies where many workers are employed in areas where they required low skill such as dump truck drivers, construction machine operators and others. But this is by far different from Kenya experience where in Kenya it is not possible to hire foreign workers except in areas where they require higher professional skill.

And as it is depicted in the figure 3 below in Ethiopia employment created through private reached its highest level in 1995, but after 1996 it was dramatically decreased.. For instance, from 1997 to 2004 it was declined and from 2005-2010 temporary employment becomes the major forms of employment created, but from 2011 onwards both temporary and permanent employment created becomes proportional, but the overall employment opportunity created has been declined. 
Figure 3: Employment Created By private Investment (1992-2017)

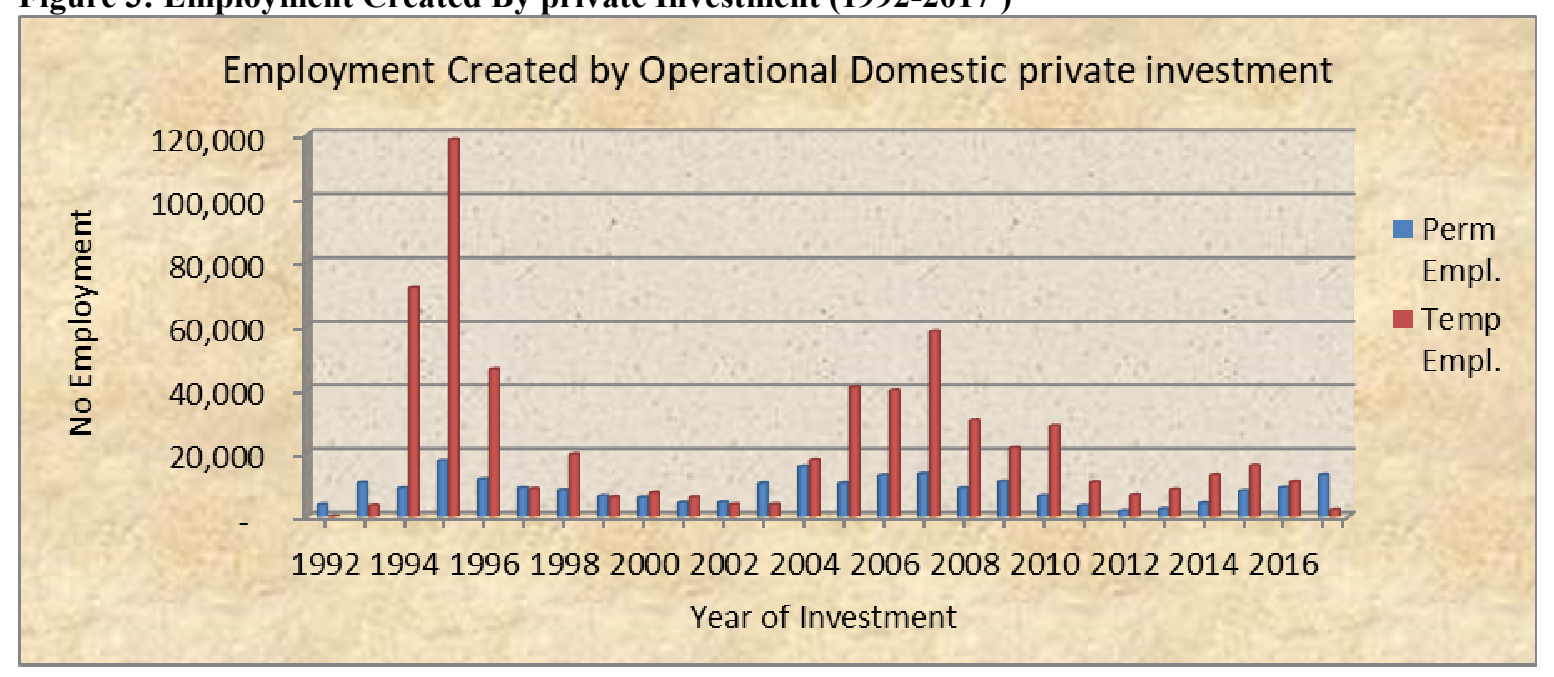

\section{4. THE COST AND BENEFIT ANALYSIS OF TAX INCENTIVE IN ETHIOPIA.}

As the primary objective of tax incentives in Ethiopia is to enhance private investment and create employment opportunity, when we evaluate this objective based on the data obtained both from secondary and primary revealed contradictory result. For example, as the data above indicates, in Ethiopia revenue forgone from duties and tax exemptions is on average $51 \%$ of total revenue and $7.5 \%$ of GDP per annum and shows an annual average growth rate of $49.22 \%$ which indicates there is significant increase in tax incentives. While the amount of investment under operation shows irregular pattern but on average it is only $20 \%$ of investors who receive investment incentives. In addition, Ethiopia government loss revenue on average 7.5 . \% of GDP per annum or a total of 384 billion birr from 2006- 2017 which is nearly equivalent to the total amount of public expenditure for poverty reduction and to supply basic services. Thus, if Ethiopia invests this huge amount of tax incentive on poverty reduction programs and supplying the basic service Ethiopia poverty level will decrease by substantial amount which can be similar with the past years poverty reduction performance. On the other hand, The Ethiopian government plans to enhance the Tax to GDP to $20 \%$, in $2017 / 18$ but it remains $14.6 \%$ as of $2012 / 13$ (MoFED, 2012/13) and even falls to $12.9 \%$ in 2013/14 and further reduced to $11 \%$ in 2017/18.

The other important point to be raised is sectoral and regional distribution of investment. With this regard as the above data indicates, we can conclude that, most of the investments are invested in sectors or areas where they could be invested without incentives except in manufacturing and Agriculture. Region wise, significant number of investments are concentrated in areas where there is better investment climate and infrastructure such as Addis, Amhara, Oromia and Tigray where investment without incentives is possible.

As the growth rate of operational investment are not proportional with revenue forgone and this implies that tax incentives granted to promote investment has failed its intended objectives. The main reasons for failure to achieve the intended objectives of tax incentives may include; loophole in investment and tax law, low monitoring and evaluation system, improper data management, high discretionary power of officials and implementation problem(abuse of tax incentive privilege) which in turn create market distortion and corruption. .In addition, the result from the annual report of ERCA shows the effectiveness of tax incentives is questionable. There are gaps in implementation and lack of strong and timely follow up system. Due to this some beneficiaries and officials may abuse the incentives.

When we compare the amount of revenue loss due to tax incentive for very one birr investment in Ethiopia as it is shown on the graph below, the absolute size of foregone revenue has been consistently decreased over the period 1995-2000, however growth rate of realized investment was quite less than 10 percent. On the other hand starting from 2001 to 2004 it starts to increase and reaches around 11 birr in 2004. From 2005 onwards it shows irregular pattern sometimes increased and other time decreased. But when we see the overall trend, revenue forgone in the form of tax incentive is by far higher than operational investment and on average it reaches 7 birr revenue forgone for one birr investment. This implies that there is large revenue forgone with low; realized investment, output, employment, and export. And finally it shows us that the intended objective of tax incentive ifs failed and reducing the countries opportunities to invest public in infrastructure, public services, social support and poverty reduction programs. 
Figure 4: Revenue Forgone For Each Addition of Investment( 1994-2018)

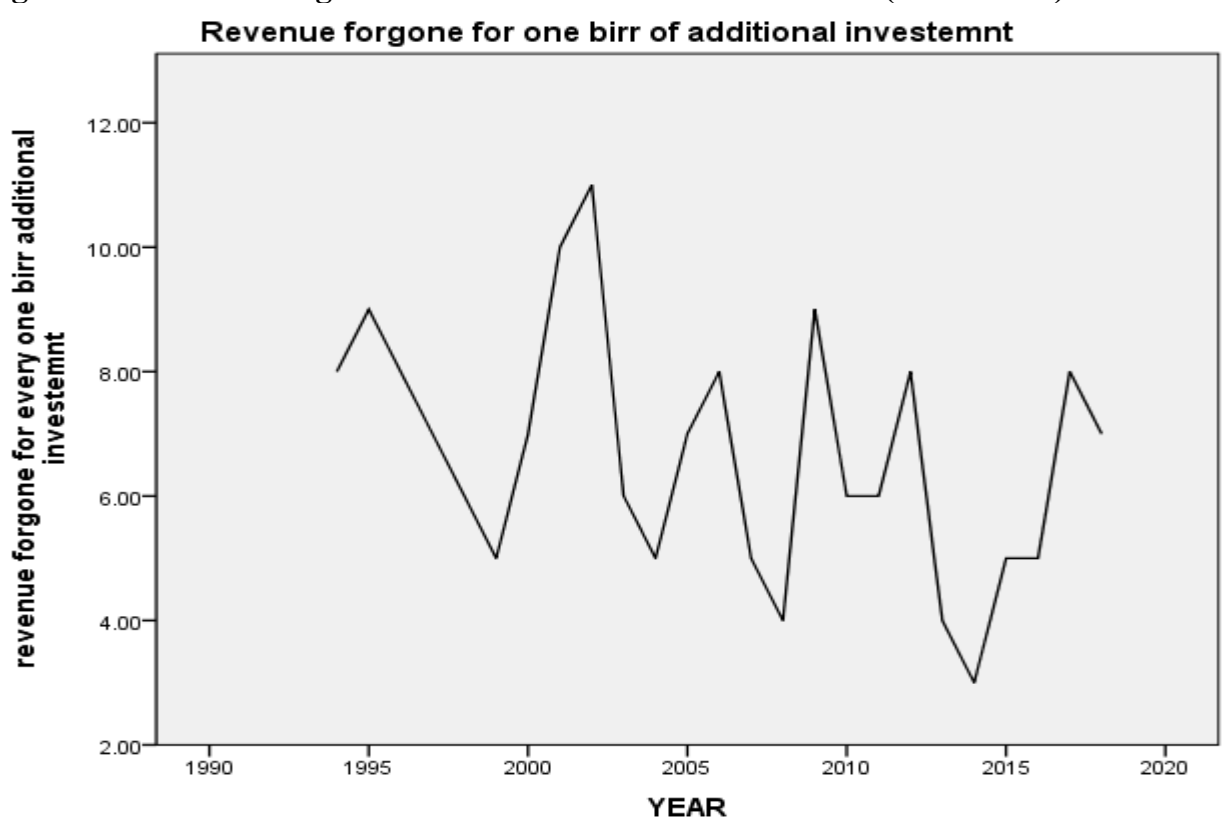

Source: EIC, 2019

Even though in the short opportunity cost of tax incentives is very large and also creates burden on its administration, but in the long run the country requires to introduce selective and administratively efficient tax incentive program and should also support with other determinates of private investment, including enhancing investment environment and avoiding the existing bureaucratic red tape.

\section{Conclusion And Recommendations}

This article employs both primary and secondary data. The primary data was collected through questionnaire from 800 respondents, and interview, and focus group discussion of officials and investors . Secondary data is gathered from different publication, documents, financial and non financial reports; and Ethiopian Investment Agency(EIA) \& Ethiopian Revenue and Tax Authority (ERCA) rules, regulations and proclamations.

Since the definitions of the cost and benefit of tax incentives are only theoretical, to arrive at the measurable definition of cost and benefit this article adopted the World Bank cost and benefit analysis framework of tax incentives.

And the result revealed that, the objective of tax incentives is failed to meet its intended objectives. This is because, the amount of employment created is not much with what is planned, and from investors who take tax incentives only $20 \%$ in number and $15 \%$ in the amount of capital they registered are operational. Furthermore, most of the investments are in areas where they can be commenced without any tax incentive and the amount of revenue forgone for one birr additional investment is about 7 birr on average. And we can conclude that; there is large revenue forgone with low; realized investment, output, employment, and export. Thus, this reduces the countries opportunities to invest public in infrastructure, public services, social support and poverty reduction programs.

Based up on the finding we can recommended that Ethiopia should:

$>$ Eliminate tax incentives which give discretionary power for officials which gives a room companies to negotiate and manipulate tax incentives.

$>$ Design tax incentives only on the basis of cost-benefit analysis, and the analysis must subject to public debate, scrutiny, and parliamentary oversight.

$>$ Ensure that any new incentive offered is grounded on legislation that makes it available to all qualifying investors, foreign or domestic. This would effectively eliminate to discretionary tax incentives.

$>$ Ensure that tax incentives, if granted, are subject to systematic monitoring and evaluation, and are revocable if the company fails to reach agreed objective.

$>$ Publish an annual overview of the costs of tax incentives as part of the annual budget, so the public can see the impact of tax incentives.

$>$ Support tax incentives with other factors that enhance investment climate.

\section{Reference list}

- Admasu Shiferaw Sioum January 2002, "Private investment and public Policy in sub saharan 
- Africa an emperical analysis", The Hague ,The Netherlands.

- Agarwal, J. P. ,1980," Determinants of Foreign Direct Investment: A Survey Weltwirtschaftliches Archiv", Volume 116, pp. 739-73.

- -Berhane, G. ,2010, "The law of corporate taxation in Ethiopia", Thesis submitted to Addis Ababa University, School of graduate studies

- Biggst, P. 2007,"Tax incentives to attract FDI in Developing countries", UNCTAD

- Bruce Bolnick 2004, "Effectiveness and Economic Impact of Tax Incentives in the SADC Region", Nathan Associates Inc., Arlington, Virginia,

- Fisheries, 2012," An overview of incentives theory and practice: A focus on the agro-processing industry in South Africa ", Danie Jordaan Directorate: Agro-processing Support Department of

- Agr -Samuel(2015), "The impacts of tax incentives in attracting foreign direct investment in Ethiopia"

- Samouel and Aram(2012), "What are the determining factors of Industrialization in Africa? ", BEJI Samouel University of Sousse.

- Sebastian James (2009), "Incentives and Investments: Evidence and Policy Implications " Investment climate advisory service of world bank group.

- Simret Mamuye Bora 2013," The effectiveness of tax incentives in attracting Foreign Direct

- Investment to Ethiopia ", The Hague, The Netherlands Vienna. iculture, Forestry and Fisheries 